\title{
The morphology of calcite crystals grown in a porous medium doped with divalent cations
}

\author{
L. Fernández-Díaz *, J.M. Astilleros, C.M. Pina \\ Dpto. Cristalografia y Mineralogía, Universidad Complutense de Madrid, 28040, Madrid, Spain
}

\begin{abstract}
Calcite crystals were grown in the presence of small concentrations $(50,200$, and $600 \mathrm{ppm})$ of divalent cations $\left(\mathrm{Ba}^{2+}, \mathrm{Sr}^{2+}, \mathrm{Co}^{2+}\right.$ and $\left.\mathrm{Mn}^{2+}\right)$ in a silica hydrogel medium. The calcite crystals grown in the presence of cations larger than $\mathrm{Ca}^{2+}\left(\mathrm{Ba}^{2+} \mathrm{Or} \mathrm{Sr}^{2+}\right)$ developed rhombohedral habits defined by $\{10 \overline{1} 4\}$ form, similar to the morphology of calcite grown in a pure gel. SEM images show that growth on $\{10 \overline{1} 4\}$ occurs by lateral advancement of layers bounded by macroscopic dendritic or jagged steps. In the case of calcite crystals grown in a gel doped with cations smaller than $\mathrm{Ca}^{2+}\left(\mathrm{Co}^{2+}\right.$ or $\left.\mathrm{Mn}^{2+}\right)$, a variety of morphologies was obtained, ranging from blocky crystals (at lower concentrations: 50 and $200 \mathrm{ppm}$ ) to peanut-like aggregates, spheres and spherulites (at 600 $\mathrm{ppm}$ ). The macroscopic morphological characteristics of such doped calcite crystals reflect closely the growth behaviour of calcite $\{10 \overline{1} 4\}$ surface at a nanoscale, reported by previous AFM studies. Morphological features have been interpreted on the basis of the modification of growing steps characteristics as a consequence of asymmetrical cation incorporation. The use of such morphologies as a criterion of biological activity is, therefore, unreliable.
\end{abstract}

Keywords: Calcite; Crystal morphology; Gel crystal growth method; Impurities

\section{Introduction}

Calcite crystals grown in sedimentary environments show a wide variety of growth morphologies. Frequently, some of these morphologies have been used as a criterion to assign a biological origin to carbonates precipitates. In 1996 the finding of carbonate globules in Martian meteorite ALH84001 sparked controversy on whether those carbonates were the result of organic or inorganic processes (McKay et al., 1996). Moreover, the habit of certain calcite and other calcite type carbonates (crystals with rounded morphologies, dumbbell-like crystals, etc)

\footnotetext{
* Corresponding author. Fax: +34 3944872.

E-mail address: 1fdiaz@geo.ucm.es (L. Fernández-Díaz).
}

have commonly been interpreted as resulting from the activity of bacteria in the crystallisation medium (Chafetz, 1986; Buczynski and Chafetz, 1991; Vasconcelos et al., 1995). Therefore, the presence in a rock of calcite crystals showing such peculiar morphologies leads researchers frequently to conclude the existence of bacteria in the medium during the growth of these crystals. However, as have been pointed out by García-Ruiz et al. (2002), using morphological criteria in order to distinguish minerals produced by living organisms can lead to erroneous conclusions. Many other factors can exert an influence on crystal morphology. Among them, the most important ones are the following: supersaturation of the medium during both nucleation and growth processes, presence of either inorganic or organic impu- 
rities, hydrødynamic factors, distribution of growth sites on the crystal surface, etc (Sunagawa, 1987).

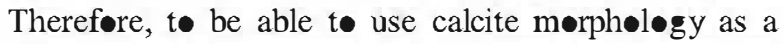
gel-gical indicator it is basic to know the physic and chemical factors involved in the generation of the different morphølegies.

Probably, the presence of impurities in the growth medium is the factor that most strongly affects the mørphøløgy $\bullet$ a crystal. When impurities incerporate inte a crystal lattice defining a sølid sølution, they will affect the growth prøcess by twø main different mechanisms: changing the characteristics of crystal surfaces, and modifying the phase sølubility. Thus, the incorp॰-

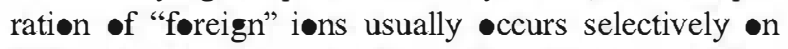
different crystalløgraphic faces, changing their surface free energies and making them rougher or smø•ther. On the ther hand, a sølubility change will determine the modification of the medium supersaturation. B॰th aspects have a definitive influence in controlling the growth mechanisms operating on the different crystallographic faces along the growth process. Thus, those faces growing more slowly will control the final growth morphøløgy. In this paper we study the effect that the presence of certain cations in the growth medium exerts

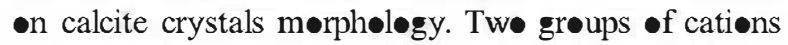
have been considered: a) cations with ionic radii smaller than $\mathrm{Ca}^{2+} \mathrm{Mg}^{2+}, \mathrm{C}^{2+}$, and $\left.\mathrm{Mn}^{2+}\right)$, which can incorp॰rate in the calcite structure forming more or less extended sølid sølutions, and b) cations with ionic radii larger than $\mathrm{Ca}^{2+}\left(\mathrm{Ba}^{2+}, \mathrm{Pb}^{2+}\right.$, and $\left.\mathrm{Sr}^{2+}\right)$, which can be incorporated inte calcite structure in small amounts. In this

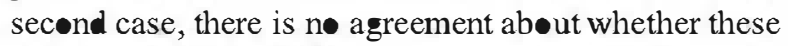

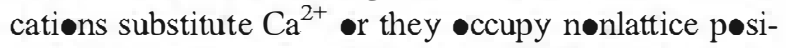
tions in calcite structure (Pingitore, 1986; Reeder et al., 1999, 2002).

The experiments of calcite crystal growth in the presence of divalent cations have been carried out by using the silica hydrogel technique. This technique has been extensively use as a method of growing crystals - f sparingly søluble salts like carbønates and sulphates (Henisch, 1988; Priet et al., 1989, 1992). Morever, it alløws reproducing most characteristics of crystallisation in sediments (García-Ruiz, 1982). Thus, in this technique, crystallization •ccurs frøm sølution by chemical reaction at low temperature in a column $\bullet$ pørous inert gel. The gel constitutes a transport medium where convection and advection are suppressed. Reactants are brought together by counter-diffusion from -pposite ends of the gel.

The calcite growth morpholøgies •btained in the experiments are different depending on whether the gel medium was doped with a divalent cation smaller or larger than $\mathrm{Ca}^{2+}$. In the case of calcite crystals grown in the presence of cations larger than $\mathrm{Ca}^{2+}$, they show a rhombohedral habit, essentially defined by all the faces belonging to the form $\{10 \overline{1} 4\}$. However, calcite crystals grown in the presence of divalent cations smaller than $\mathrm{Ca}^{2+}$ sh॰w a variety of morphøløgies that, in all the cases considered, have commøn aspects: crystals are slightly elongated along the $\overline{3}$ axis and have a cleft in

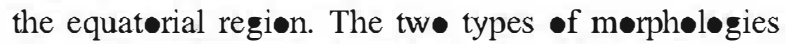
-btained are interpreted on the basis of the gemetrical characteristics of the steps operating during growth of

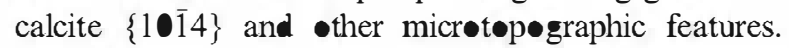

\section{Experimental}

The crystallisation of calcite was carried out in a double diffusion system as shøwn in Fig. 1. The experimental arrangement consist in a U-tube where a column of silica hydrøgel $(150 \mathrm{~mm}$ løng and $9 \mathrm{~mm}$ in diameter) eccupies the horizontal branch, while the vertical branches (A and $\mathrm{B}$ ) correspønd to the reservoirs of the parent solutions and were filled with $8 \mathrm{~cm}^{3}$ of $\mathrm{CaCl}_{2}(0.5 \mathrm{M})$ and $\mathrm{Na}_{2} \mathrm{CO}_{3}(0.5 \mathrm{~N})$, respectively. The gel was prepared by acidification with $\mathrm{HCl}(1 \mathrm{~N})$ of a sødium silicate $\left(\mathrm{Na}_{2} \mathrm{Si}_{3}\right)$ sølution (Merck, sp. Gr.: $\left.1.059 \mathrm{~g} \mathrm{~cm}^{-3}, \mathrm{pH} 11.2\right)$ to the desired initial $\mathrm{pH}(5.5)$ and poured in the U-tube. For the conditions established here, the silica hydrogel contains abøut $95.6 \%$ water filling the pores and $\mathrm{NaCl}$ as a søluble by-product. The solution is trapped within micron-sized pores, what makes it stagnant (Henisch, 1988). Mass transfer •ccurs via mølecular diffusion and leads to the develøpment $\bullet$ gradients of $\mathrm{pH}$ and concentration along the gel column. Separate experiments were carried out to study the influence of the presence of $\mathrm{Mn}^{2+}, \mathrm{C}^{2+}, \mathrm{Ba}^{2+}$, and $\mathrm{Sr}^{2+}$ in the aque us sølution on the growth of calcite. Small concentrations of these impurities $(50,200$, and

A

B

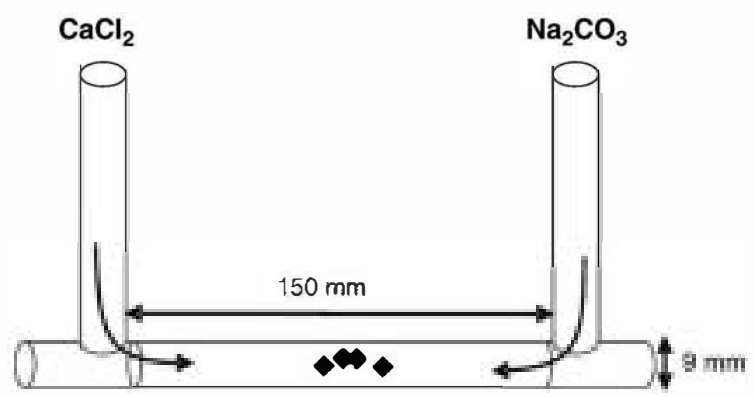

Gel column

doped with divalent cation

Fig. 1. Schematic representation of the experimental system (U-tube). 
$600 \mathrm{ppm}$ ) were added to the sodium silicate sølution during the gel preparation. Thus, the gel column had a homogeneous concentration of additive. The experiments were carrie out at $25 \pm 0.1^{\circ} \mathrm{C}$. The growth evolution of the crystals was monitored by optical microscopy. The experiments were stopped a year after nucleation. Then crystals were recovered by partially disselving the gel in a $\mathrm{NaOH}(1 \mathrm{M})$ solution. The crystals were identified as calcite by X-ray diffraction and their morphølogy was studied by Scarming Electron Microscopy (JEOL $8600 \mathrm{MXA}$ and JEOL JSM6400).

\section{Results and discussion}

\subsection{Growth of calcite}

The morphølogy of calcite crystals grøwn frøm pure aque us sølutions in silica hydregel is defined by the rhombohedron $\{10 \overline{1} 4\}$. During the first stages of growth prøcess, $\{10 \overline{1} 4\}$ faces are essentially flat. Høw-

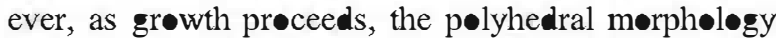
becomes disturbed as a consequence of the fact that growth occurs preferentially along certain directions. Thus, all the faces belonging to the form $\{10 \overline{1} 4\}$ develıp large steps of which tw॰ edges are clearly de fined by their intersection at the $\overline{3}$ axis. The other two edges appear diffuse and broken in steps. As a result, crystals become hopper-like, with faces that are rough and depressed in their central region. The final morphøløgy shows only faces belonging to the form $\{10 \overline{1} 4\}$ restricted th these areas that are close to the two edges meeting in the $\overline{3}$ axis. Fig. 2 shows such a typical development -f the edges on $\{10 \overline{1} 4\}$ calcite crystals. When these crystals are oriented with their $\overline{3}$ axis vertical, their

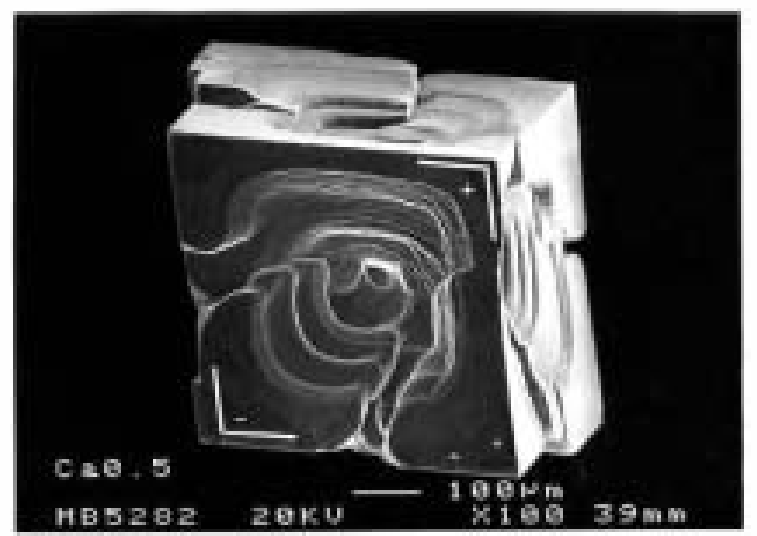

Fig. 2. Calcite crystal obtained in a gel experiment in absence of doping cations. The different development of the (1014) face edges ("+" and "-") can be clearly observed. equatorial region appears as a marked cleft, with peaks and troughs that alternate every $60^{\circ}$, reproducing the $\overline{3}$ symmetry. Such a morphølogy has been commonly observed in calcite- type crystals grown at high supersaturation (Franke et al., 1979; Prieto et al., 1981; Heijnen, 1985; Fernández-Díaz et al., 1996) and described in detail by Dominguez Bella and García-Ruiz (1987), Fernández-Gønzález et al. (1999) and Astillerøs (2001). It is important to note that, regardless of the degree of supersaturation, the form $\{1014\}$ defines always the morphology of calcite crystals grown in a diffusion-reaction system. Supersaturation levels during the growth process only affect the roughness of the rhømbøhedral faces. When grøwth •ccurs under higher supersaturation levels, the cleft observed in the equatorial region appears more evident and the surfaces are rougher than at moderate supersaturation of the growth medium. This is a consequence of the development of supersaturation gradients around the crystal (Berg, 1938).

The dominance of the calcite form $\{10 \overline{1} 4\}$ for wide supersaturation ranges reflects the strong contrøl of the calcite structure on its crystal morphølogy. This is clearly evidence by the structural analysis developed by Paquette and Reeder (1995) and Staudt et al. (1994). In the calcite structure the most stable Periodic Bond Chain (PBC) runs along $\langle\overline{4} 41\rangle$ directions (Heijnen, 1985), with two different pairs of crystalløgraphically equivalent directions being related by the c-glide: the positive directions $[\overline{4} 41]_{+}$and $[48 \overline{1}]_{+}$and the negative directions $[\overline{4} 41]_{-}$and $[48 \overline{1}]_{-}$(notation according to Staudt et al., 1994). As a consequence of the orientation -f the expøsed carbønate grøups (Reeder and Rakøvan, 1999), steps parallel to positive and negatives directions have non-equivalent step edge geometries. Positive steps contain large and open kink sites, while kink sites in negative steps have a more constrained gemetry. These structural characteristics determine the growth behaviour of a calcite $\{10 \overline{1} 4\}$ surface, as cœnfirme by AFM experiments carried out by several authors (Hillner et al., 1992; Gratz et al., 1993). The growth $\bullet$ the faces belonging to the form $\{10 \overline{1} 4\}$ at a mølecular scale eccurs by a layer-by-layer mechanism, controlled by the advancement of steps parallel t॰ $\langle\overline{4} 41\rangle$ directions. The grøwth prøcess is highly anisøtropic, with a pair of steps moving rapidly, while the other pair of steps advances slowly. Those steps that advance rapidly are parallel t॰ positive directions, i.e. they contain kink sites that are more open. Conversely, the steps that move slowly are parallel to negative directions and contain constrained kink sites. This growth behaviour at a molecular scale leads to the development of the 
typical macroscopic calcite rhømbøhedra (Teng et al., 2000). The existence of more open and constrained kink sites in non-equivalent growth steps parallel to $\langle\overline{4} 41\rangle$ directions can als• explain the anisøtropic development of roughness on calcite rhombohedral edges as supersaturation increases. Thus, the twø well-de fined edges that meet in $\overline{3}$ axis correspond to [441] $]_{+}$and $[48 \overline{1}]_{+}$, while the two diffuse edges are parallel to [441] $]_{-}$and $[48 \overline{1}]_{-}$. At this pøint it is worth mentioning that supersaturation only modifies the relative development of the nøn-equivalent rhømbøhedral edges. Therefore, any other morphøløical change in calcite will reflect the influence of other external factors, e.g. incorporation of impurities. In the next sections the morphology modifications due to the incorporation of cations larger and smaller than $\mathrm{Ca}^{2+}$ int the calcite structure will be discussed.

\subsection{Growth of calcite doped with divalent cations}

The experiments carried out using silica gel doped with different divalent cations have produce calcite crystals shøwing a variety $\bullet$ m morph $\bullet$ gies. Since calcite forms more or less restricted sølid sølutions with all the considered cations, the observed morphological variability can be attributed to the incorporation of these cations int the calcite lattice. Such incorporation is n॰t isotrøpic as has been demønstrated by Paquette and Reeder (1990, 1995) and Hay et al. (2003).

\subsubsection{Cations larger than $\mathrm{Ca}^{2+}: \mathrm{Ba}^{2+}, \mathrm{Sr}^{2+}$}

The morphology of calcite crystals grown in a silica hydrøgel doped with $\mathrm{Ba}^{2+}$ or $\mathrm{Sr}^{2+}$ is very similar to the morphølogy of calcite crystals grown in a pure gel. Thus, the habit is controlled by the $\{1014\}$ rhømb hedron form. Moreover, these faces appear to show steps

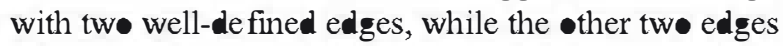
appear to be rough and distorted. Fig. $3 \mathrm{a}$ and $\mathrm{b}$ show calcite crystals grown in a gel doped with 200 and 600 $\mathrm{ppm}$ of $\mathrm{Sr}^{2+}$, respectively. It is interesting to note that, as can be observed in both images, the growth of the $\{1014\}$ form $\bullet$ ccurs by lateral advancement of layers from the well-de fined edges to the central region of the face. Macroscopic dendritic or jagged steps bounded these layers. The re-entrants of the steps løbes are especially $\bullet$ bvious when the concentration of the doping cation in the medium is high. In such a case, several thick growth layers pile up on $\{10 \overline{1} 4\}$ surface. As a result, the surface develops a bløcky appearance. Møre-ver, $\bullet$ ne pair of $\{10 \overline{1} 4\}$ face edges shøws clear striations and the first steps of the development of a vicinal surface.
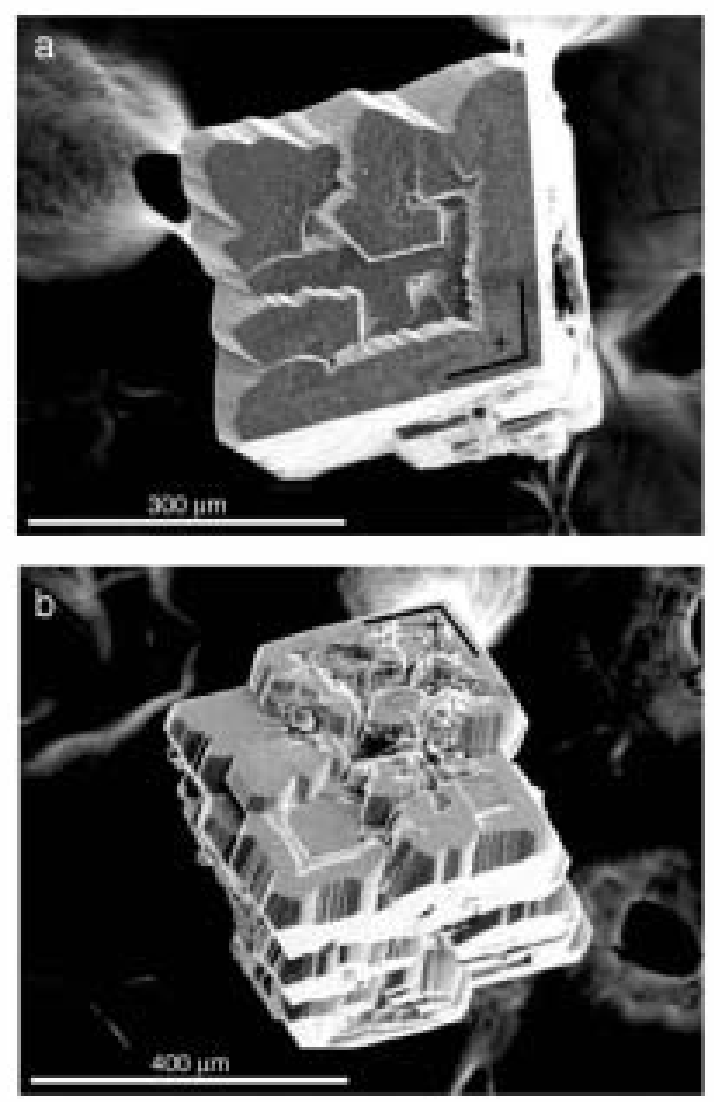

Fig. 3. Calcite crystals grown in a gel medium doped with $\mathrm{Sr}^{2+}$ : The amount of $\mathrm{Sr}^{2+}$ in the interstitial solution was (a) $200 \mathrm{ppm}$ and (b) 600 ppm. The jagged appearance of positive steps can be observed.

The macrøscopic characteristics of faces belønging to form $\{10 \overline{1} 4\}$ in calcite crystals grown in a gel medium doped with either $\mathrm{Ba}^{2+}$ or $\mathrm{Sr}^{2+}$ are a close reflection of the microscopic features øbserved on such surfaces during grøwth in the presence of any of these cations at a molecular scale. According to AFM observations carried out by Astilleres et al. (2000, 2003), the well defined pair of edges on a calcite $(10 \overline{1} 4)$ face must be parallel to the positive directions $[\overline{4} 41]_{+}$and $[48 \overline{1}]_{+}$, while the rough pair of edges must be parallel to the negative directions $[\overline{4} 41]_{-}$and $[48 \overline{1}]_{-}$. As these authors showed, the growth of calcite $\{10 \overline{1} 4\}$ surface in the presence $\bullet \mathrm{Ba}^{2+}$ and $\mathrm{Sr}^{2+}$ exhibits common features at an atomic scale. In the same way as calcite growth from a pure solution, the process is controlled by the advance-

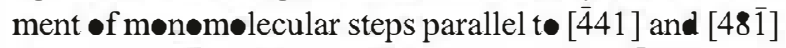
directions. However, in this case while $[\overline{4} 41]_{+}$and $[48 \overline{1}]_{+}$steps advance showing jagged edges, $[\overline{4} 41]_{-}$ and $[48 \overline{1}]_{-}$remain practically immobile. Moreover, the degree of roughness of the positive steps edges increases with the concentration of "foreign" cation in the solution and, for high concentrations of $\mathrm{Ba}^{2+}$ or $\mathrm{Sr}^{2+}$ 
in the solution, the newly grown positive step edges contrast with the original region, indicating that they are thicker than the initial steps (see Fig. 4). The presence of both cations in sølution als reduces the velocities of the positive steps in comparison to their advancement velocity when growth $\bullet$ ccurs from a pure sølution. These -bservations confirmed the previsions of the model by Paquette and Reeder (1995) that consider a preferential incorp॰ration of large cations int steps with $\bullet$ pen kinks $\left([\overline{4} 41]_{+}\right.$and $\left.[48 \overline{1}]_{+}\right)$. Such a preferential incorporation explains the roughening of these steps, their thickening and their decreasing velocity. The difficulty of large

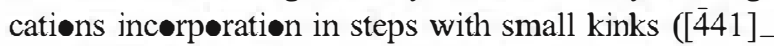
and $[48 \overline{1}]_{-}$) determines the blockage of these steps and explains that they remain basically straight during the growth process.

\subsubsection{Cations smaller than $\mathrm{Ca}^{2+}: \mathrm{Co}^{2+}, \mathrm{Mn}^{2+}$}

The growth of calcite crystals in a gel doped with $\mathrm{C}^{2+}$ or $\mathrm{Mn}^{2+}$ shows common aspects, independently of the cation considered. A variety of morphølogies, ranging from bløcky crystals to peanut-like aggregates, spheres and spherulites, have been $\bullet$ btained, depending -n the concentration of each divalent cation in the gel column. Thus, when the concentration of the "foreign" cation is lower $(50,200$ ppm) blocky calcite crystals are -btained. These crystals show a habit elongated aløng $c$ axis. The habit is controlle by both $\{10 \overline{1} 4\}$ and $\{022 \overline{1}\}$ forms (see Fig. 5). Such morphøløgy has a marked cleft

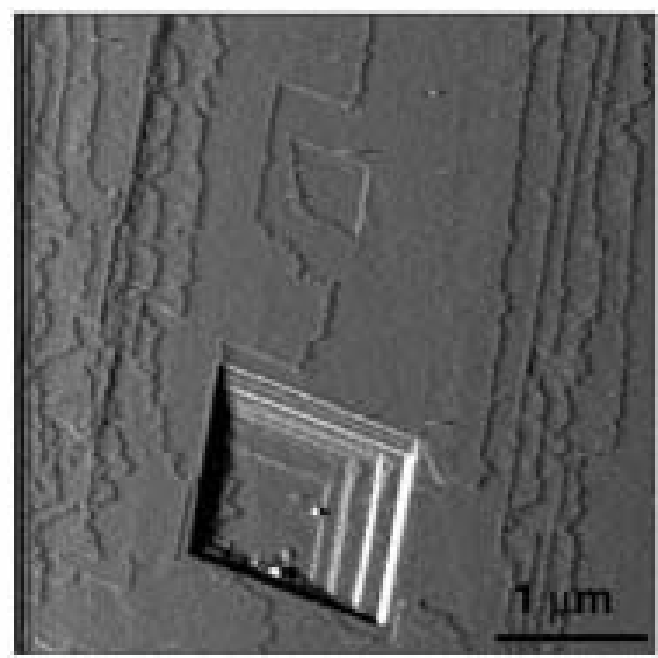

Fig. 4. AFM image showing the development of lobes in the positive steps of a calcite $\left(1 \mathbf{1}^{1}\right)$ surface. The composition of the grown

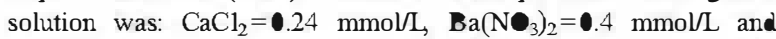
$\mathrm{Na}_{2} \mathrm{CO}_{3}=.3 \mathrm{mmol} / \mathrm{L}$. The distance between lobes is approximately $80 \mathrm{~nm}$. Note the contrast between the newly grown edges and the original surface, indicating the thickening of the steps as a consequence of $\mathbf{B a}^{2+}$ incorporation.
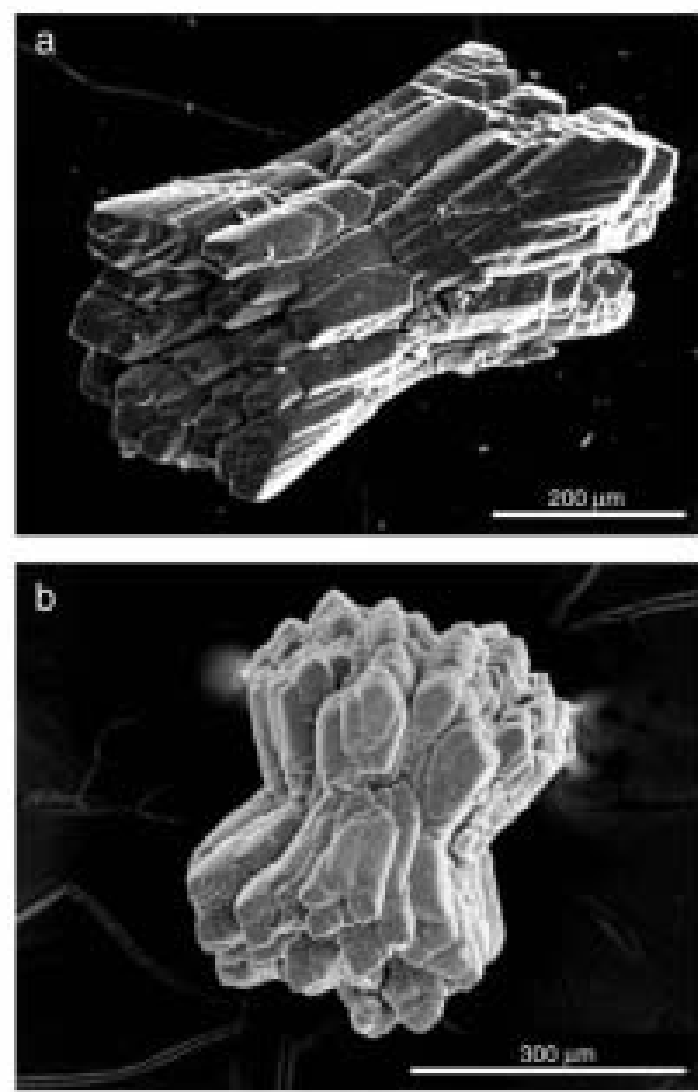

Fig. 5. Calcite crystals grown in a gel medium doped with (a) $50 \mathrm{ppm}$ of $\mathrm{Co}^{2+}$, and (b) $50 \mathrm{ppm}$ of $\mathrm{Mn}^{2+}$.

in the equatorial region as well as has been observed in calcite crystals grown both in pure gel and in gel doped with divalent cations larger than $\mathrm{Ca}$. Moreover, these crystals can hardly be considered single crystals. They are constitute by numerøus bløcks, slightly misøriented between $\bullet$ ne to each $\bullet$ ther. In addition, those crystals show clear evidences of split grøwth processes, which are more intense when growth $\bullet c c u r s$ in the presence of higher cøncentratiøns $\bullet$ f foreign catiøns. The prøgress $\bullet$ the splitting leads to the development of aggregates with evident rounded surfaces and, in the extreme case, of sheaf-like and peanut-like morph $\bullet$ logies (Fig. 6). A very similar morphøløgical evølution was $\bullet$ bserved by Fernández-Díaz et al. (1996) for the grøwth of calcite in a silica gel medium doped with $\mathrm{Mg}^{2+}$.

Astilleros et al. (2002) and Freij et al. (2004) studied the nanoscopic evolution of calcite faces belonging to the $\{10 \overline{1} 4\}$ form in the presence of $\mathrm{Mn}^{2+}$ and $\mathrm{C}^{2+}$. Only low concentrations of $\mathrm{Mn}^{2+}$ and $\mathrm{C}^{2+}$ present in the solution are require to affect dramatically the growth of calcite $(10 \overline{1} 4)$ faces in contrast to the effect of $\mathrm{Ba}^{2+}$ and $\mathrm{Sr}^{2+}$. For low supersaturated solutions, the addition of $0.01 \mathrm{~mm} \bullet \mathrm{l}$ of $\mathrm{C}^{2+}$ or $\mathrm{Mn}^{2+}$ is enough to 

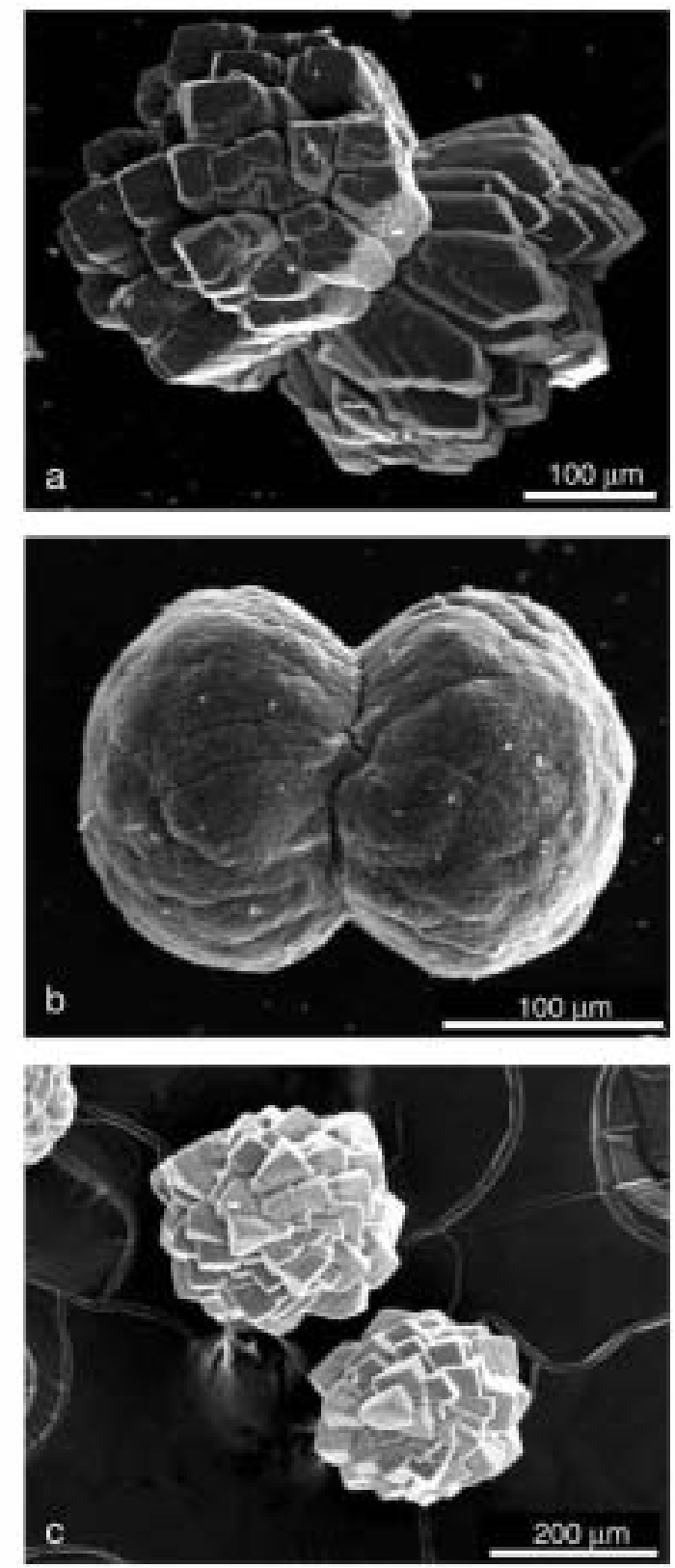

Fig. 6. Calcite crystals grown in a gel medium doped with (a) 200 ppm of $\mathrm{Co}^{2+}$, (b) $600 \mathrm{ppm}$ of $\mathrm{Co}^{2+}$, and (c) $200 \mathrm{ppm}$ of $\mathrm{Mn}^{2+}$.

slow down significantly the step advancement. Higher cation concentrations $([\mathrm{Mn}]=[\mathrm{C} \bullet]=\mathbf{0 . 0 5} \mathrm{mm \bullet l})$ almøst completely stop the advancement of steps.

As has been mentioned abøve, the morphøløgical variability observed in the growth of calcite in the presence of both cations basically coincides with previøus •bservations on the influence $\bullet \mathbf{M g}^{2+} \bullet$ calcite crystal habits (Fernández-Díaz et al., 1996). The main features of calcite $\{10 \overline{1} 4\}$ surface at nanoscale when growth $\bullet$ ccurs from a $\mathrm{Mg}^{2+}$-bearing sølution have been widely described by Davis et al. (2000, 2004). According to these authors the addition of $\mathrm{Mg}^{2+}$ to the growth sølution exerts an inhibitory effect that causes step edges to roughen. Such roughening preferentially affects those steps parallel to the negative directions $[\overline{4} 41]_{-}$and $[48 \overline{1}]_{-}$as a result of differences in the mølecular-scale structure of step edges, althøugh at bigher $\mathrm{Mg} / \mathrm{Ca}$ ratios in the growth sølutions roughen

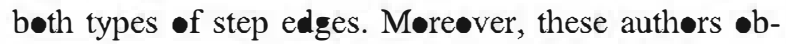
serve that growth is preferentially inhibited in the corners between positive and negative directions, where the contact between regions with different composition should be occurring. This must alse be the situation when grøwth $\bullet$ ccurs from sølutions containing $\mathrm{C}^{2+}$ •r

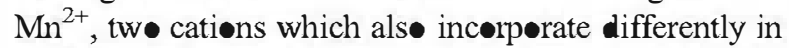
positive and negative steps. Therefore, an especially strong inhibitory effect in the corners between positive and negative steps should be common to all divalent cations smaller than $\mathrm{Ca}^{2+}$ incorporating inte calcite $\{10 \overline{1} 4\}$ surfaces. Such an effect could form the basis of the develøpment $\bullet$ the marke equatorial clefts -bserved in all calcite crystals grøm in the presence of any $\bullet$ these cations. The mørphøløgical changes prøposed by Davis et al. (2004) basically coincide with the modifications that we have found in the habit of calcite crystals grown in the presence of divalent cations smaller than $\mathrm{Ca}^{2+}$ : elongation along $c$ direction and emergence of rough pseudofacets that lead to the development of a new crystallographic form. Although these authors have propose $\{01 \overline{1}\}$ as the new form, we find that the habit of calcite crystals grown in the presence of $\mathrm{C}^{2+}$ or $\mathrm{Mn}^{2+}$ is defined by $\{10 \overline{1} 4\}$ and strongly pseudofaceted $\{02 \overline{2} 1\}$ forms.

\section{Conclusions}

Growth experiments presented in this paper show that the morph $\bullet$ gy of calcite is strongly affected by the incorporation of divalent cations in its structure. Depending on both the degree of cation incorporation and the relative size of each particular cation with respect to $\mathrm{Ca}^{2+}$, different calcite habits have been $\bullet b-$ served. When the crystallization medium is doped with cations larger than $\mathrm{Ca}^{2+}\left(\mathrm{Ba}^{2+}\right.$ and $\left.\mathrm{Sr}^{2+}\right)$ the degree of isømorphic substitution in the calcite structure is limited and crystal morphølogy only slightly differs from the morph $\bullet$ gy $\bullet$ pure calcite, i.e. the habit is dominated by the $\{10 \overline{1} 4\}$ rhombohedron. However, the presence of $\mathrm{Ba}$ and $\mathrm{Sr}$ in the medium leads to the development of highly stepped faces that provide the calcite crystals a blocky appearance. In contrast, when the crystallization medium is doped with cations smaller than $\mathrm{Ca}^{2+}\left(\mathrm{C}^{2+}\right.$ 
and $\mathrm{Mn}^{2+}$ ) their easier incorperation inte the calcite structure results in a wider variety of crystal habits as a function of the "foreign" cation concentration in the growth medium. Thus, as $\mathrm{C}^{2+}\left(\circ \mathrm{Mn}^{2+}\right)$ concentration increases calcite habits vary from blocky crystals to peanut-like aggregates and spherulites. Some of these calcite morphølogies have been usually related to biølogical activity. Since our experiments are strictly "inorganic", we must conclude that the use of some peculiar morphologies of natural calcites as the only criterion to prove their biølogical origin is not reliable.

\section{Acknowledgements}

Constructive reviews by C.F. Wøensdregt and J.M. García-Ruiz have helped a great deal in revising the manuscript. Authørs thank Mrs. Ch. V. Putnis (Institut für Mineraløgy Münster, Germany) for helping to -btain søme SEM images. C. M. Pina and J.M. Astilleros acknowledge the Spanish Ministry of Education and Science for financial support (Ramón y Cajal contract). The Spanish Ministry of Education and Science (Prøject BTE2002-00325) supported this work als• financially. [LMW]

\section{References}

Astilleros, J.M., 2001. Estudio integrado de la cristalización de soluciones sólidas no ideales: $(\mathrm{Ca}, \mathrm{M}) \mathrm{C}_{3}(\mathrm{M}=\mathbf{B a}, \mathrm{Sr}, \mathrm{Mn})$. Ph. D Thesis. Universidad Complutense. Madrid.

Astilleros, J.M, Pina, C.M., Fernández-Díaz, L., Pumis, A., 2000. The effect of barium on calcite $(10 \overline{1} 4)$ surfaces during growth. Geochim. Cosmochim. Acta 64, 2965-2972.

Astilleros, J.M, Pina, C.M., Femández-Díaz, L., Putnis, A., 2002. Molecular scale surface processes during the growth of calcite in the presence of manganese. Geochim. Cosmochim. Acta 66, 3177-3189.

Astilleros, J.M, Pina, C.M., Femández-Díaz, L., Putnis, A., 2003 Metastable phenomena on calcite $\{10 \overline{1} 4\}$ surfaces growing from $\mathrm{Sr}^{2+}-\mathrm{Ca}^{2+}-\mathrm{CO}_{3}^{2-}$ aqueous solutions. Chem. Geol. 193, 93-107.

Berg, W.F., 1938. Crystal growth from solutions. Proc. R. Soc. Lond., A $164,79-95$.

Buczynski, C., Chafetz, H.S., 1991. Habit of bacterially induced precipitates of calcium carbonate and the influence of medium viscosity on mineralogy. J. Sediment. Petrol. 61, 226-233.

Chafetz, H.S., 1986. Marine peloids: a product of bacterially induced precipitation of calcite. J. Sediment. Petrol. 56, $812-817$.

Davis, K.J., Dove, P.M., De Yoreo, J.J., 2000. The role of $\mathrm{Mg}^{2+}$ as an impurity in calcite grouth. Science 290, 1134-1137.

Davis, K.J., Dove, P.M., Wasylenki, L.E., De Yoreo, J.J., 2004. Morphological consequences of differential $\mathrm{Mg}^{2+}$ incorporation at stucturally distinct steps on calcite. Am. Mineral. 89, $714-720$

Dominguez Bella, S., García-Ruiz, J.M., 1987. Análisis morfológico y textural de monocristales de calcita crecidos en geles de TMS a $\mathrm{pH}=7$. Bol. Soc. Esp. Mineral. 10, 271-276.
Fernández-Díaz, L., Pumis, A., Prieto, M., Pumis, C.V., 1996. The role of magnesium in the crystallisation of calcite and aragonite in a porous medium. J. Sediment. Res. 66, 482-491.

Fernández-González, A., Prieto, M., Pumis, A., López-Andrés, S., 1999. Concentric zoning patterns in crystallizing $(\mathrm{Cd}, \mathrm{Ca}) \mathrm{CO}_{3}$ solid solutions from aqueous solutions. Mineral. Mag. 63, $331-343$

Franke, W., Ittyachen, M.A., Mohanan Pillai, K., 1979. Scanning electron microscopic studies on different habits of gel grown manganese carbonate crystals. Pramana 13, 293-297.

Freij, S.J., Pumis, A., Astilleros, J.M., 2004. Nanoscale observations of the effect of cobalt on calcite grouth and dissolution. J. Cryst. Growth 267, 230-288.

García-Ruiz, J.M., 1982. Crystal growth in gels as a laboratory analogous of the natural crystallization. In: Rodríguez, R., Sunagawa, I. (Eds.), Crystal Growth Processes in Sedimentary Environments, Estudios Geológicos, vol. 38, pp. 209-225.

García-Ruiz, J.M., Camerup, A., Christy, A.G., Welham, N.J., Hyde, S.T., 2002. Morphology: an ambiguous indicator of biogenicity. Astrobiology 2, 335-351.

Gratz, AJ., Hillner, P.E., Hansma, P.K., 1993. Step dynamics and spiral growth on calcite. Geochim. Cosmochim. Acta 57, 491-495.

Hay, M.B., Workman, R.K., Manne, S., 2003. Mechanisms of metal ion sorption on calcite: composition mapping by lateral force microscopy. Langmuir 19, 3727-3740.

Heijnen, W.M.M., 1985. The morphology of gel grown calcite. Neues Jahrb. Mineral.-Mon.hefte \&, 357-362.

Henisch, H.K., 1988. Crystals in Gels and Liesegang Rings. Cambridge University Press. $197 \mathrm{pp}$

Hillner, P.E., Gratz, A.J., Manne, S., Hansma, P.K., 1992. Atomicscale imaging of calcite grouth and dissolution in real time. Geology 20, 359-362.

McKay, D.S., Gibson, E.K., Thomas-Kerpta, K., Vali, H., Romanek, C.S., Clement, S.J., Chiller, X.D.F., Macchiling, C.R., Zarc, R.N., 1996. Search for past life on Mars: possible relic biogenic activity in Martian meteorite ALH 84001 . Science 273, $924-930$

Paquette, J., Reeder, R.J., 1990. New type of compositional zoning in calcite: insights into crystal-grouth mechanisms. Geology 18, $1244-1247$.

Paquette, J., Reeder, R.J., 1995. Relationships between surface structure, growth mechanism, and element incorporation in calcite. Geochim. Cosmochim. Acta 59, 735-749.

Pingitore Jr., N.E., 1986. Modes of coprecipitation of $\mathbf{B a}^{2+}$ and $\mathrm{Sr}^{2+}$ with calcite. In: Davis, J.A., Hayes, K.F. (Eds.), Geochemical Processes at Mineral Surfaces, ACS Symp. Ser, vol. 323, pp. $574-586$

Prieto, M., García-Ruiz, J.M., Amorós, J.L., 1981. Growth of calcite crystals with non-singular faces. J. Cryst. Growth 52, $864-867$

Prieto, M., Fernández-Díaz, L., López-Andrés, S., 1989. Supersaturation evolution and first precipitate location in crystal growth in gels: application to barium and strontium carbonates. J. Cryst. Growth 98, 447-460.

Prieto, M., Pumis, A., Arribas, J., Fernández-Díaz, L., 1992. Ontogeny of barite crystals grown in a porous medium. Mineral. Mag 56, $587-598$.

Reeder, R.J., Rakovan, J., 1999. Surface stuctural controls on wace element incorporation during crystal grouth. In: Jamtveit, B., Meakin, P. (Eds.), Growth, Dissolution and Pattem Formation in Geosystems. Kluwer Academic Publishers. 
Reeder, R.J., Lamble, G.M., Northrup, P.A., 1999. XAFS study of the coordination and local relaxation around $\mathrm{Co}^{2+}, \mathrm{Zn}^{2+}, \mathrm{Pb}^{2+}$, and $\mathrm{Ba}^{2+}$ race elements in calcite. Am. Mineral. 84, 1049-1060.

Reeder, R.J., Elzinga, E.J., Rouff, A., 2002. Coordination of some metals sorbed at the calcite-water interface. Geochim. Cosmochim. Acta 66, A628.

Staudt, W.J., Reeder, R.J., Schoonen, M.A.A., 1994. Surface structural controls on compositional zoning of $\mathrm{S}_{4}^{2-}$ and $\mathrm{Se}_{4}^{2-}$ in synthetic calcite single crystals. Geochim. Cosmochim. Acta 58, $2087-2098$
Sunagawa, I., 1987. Morphology of minerals. In: Sunagawa, I. (Ed.), Morphology of Crystals, V. 2. Terra Scientific Publishing Company (TERRAPUB), Tokyo, pp. 511-587.

Teng, H.H., Dove, PM, DeYoreo, J.J., 2000. Kinetics of calcite growth: surface processes and relationships to macroscopic rate laws. Geochim. Cosmochim. Acta 64, 2255-2266.

Vasconcelos, C., McKenzie, JA., Bemasconi, S., Grujic, D., Tien, A.J., 1995. Microbial mediation as a possible mechanism for natural dolomite formation at low temperatures. Nature 377, $220-222$. 